\title{
MORPHOSTRUCTURAL CHARACTERIZATION OF SOIL CONVENTIONALLY TILLED WITH MECHANIZED AND ANIMAL TRACTION WITH AND WITHOUT COVER CROP(1)
}

\author{
Ricardo Ralisch ${ }^{(2)}$, Edinei de Almeida ${ }^{(3)}$, Adriana Pereira da Silva(4), \\ Osvaldo Coelho Pereira Neto ${ }^{(5)}$ \& Maria de Fátima Guimarães ${ }^{(6)}$
}

\begin{abstract}
SUMMARY
The structural stability and restructuring ability of a soil are related to the methods of crop management and soil preparation. A recommended strategy to reduce the effects of soil preparation is to use crop rotation and cover crops that help conserve and restore the soil structure. The aim of this study was to evaluate and quantify the homogeneous morphological units in soil under conventional mechanized tillage and animal traction, as well as to assess the effect on the soil structure of intercropping with jack bean (Canavalia ensiformis L.). Profiles were analyzed in April of 2006, in five counties in the Southern-Central region of Paraná State (Brazil), on family farms producing maize (Zea mays L.), sometimes intercropped with jack bean. The current structures in the crop profile were analyzed using Geographic Information Systems (GIS) and subsequently principal component analysis (PCA) to generate statistics. Morphostructural soil analysis showed a predominance of compact units in areas of high-intensity cultivation under mechanized traction. The cover crop did not improve the structure of the soil with low porosity and compact units that hamper the root system growth. In areas exposed to animal traction, a predominance of cracked units was observed, where roots grew around the clods and along the gaps between them.
\end{abstract}

Index terms: soil tillage, cultural profile, morphological homogeneous units, structural recovering.

\footnotetext{
(1) Submitted March 2010, approved September 2010.

(2) Scientific Researcher of the Department of Agronomy at the Universidade Estadual de Londrina - UEL. Rodovia Celso Garcia Cid, Pr 445 Km 380. E-mail: ralisch@uel.br

(3) Masters student in Agronomy at the Universidade Estadual de Londrina - UEL. E-mail: edineialm@gmail.com

(4) Doctorate student in Agronomy at the Universidade Estadual de Londrina - UEL. E-mail: drikapera@yahoo.com.br

(5) Scientific Researcher in the Department of Geography at the Universidade Estadual de Londrina - UEL. E-mail: coelho@uel.br

(6) Scientific Researcher in the Department of Agronomy at the Universidade Estadual de Londrina - UEL. E-mail: mfatima@uel
} 


\title{
RESUMO: CARACTERIZAÇÃO MORFOESTRUTURAL DE SOLO SOB TRAÇÃO MECÂNICA E ANIMAL SUBMETIDO A PLANTA DE COBERTURA
}

\begin{abstract}
A estabilidade estrutural do solo e sua capacidade de reestruturação dependem do preparo do solo e do manejo das culturas adotados no sistema de produção. Uma estratégia apontada para amenizar os efeitos do preparo do solo é a adoção de rotação de culturas e de culturas de cobertura, que contribuem para preservar ou recuperar a estrutura do solo. Os objetivos deste trabalho foram avaliar e quantificar as unidades morfologicamente homogêneas, em solo sob preparo convencional com tração mecânica e animal, bem como avaliar o efeito do sistema de sucessão de culturas e do consórcio com a leguminosa "feijão-de-porco"(Canavalia ensiformis L.) na estrutura do solo. Os perfis foram analisados em abril de 2006, em cinco municípios da região centro-sul do Paraná, em áreas de produção familiar, durante o ciclo da cultura de milho (Zea mays L.), com ou sem consórcio com feijão-de-porco. Essa análise foi realizada por meio da medição da área das estruturas encontradas no perfil cultural do solo utilizando um SIG (Sistema de Informação Geográfica) e, posteriormente, avaliada pelo método estatístico de análise de componentes principais. Constatou-se, por meio da análise morfoestrutural, que nas áreas com maior intensidade de preparo do solo, devido à tração mecânica, houve predominância das unidades compactadas, e a planta de cobertura não exerceu efeito na recuperação da estrutura do solo, com presença de unidades compactadas de baixa porosidade, que dificultaram o crescimento do sistema radicular das plantas. Já nas áreas manejadas com tração animal foi observado predominio das unidades fissuradas, onde as raízes envolviam os torrões do solo, nos pontos de ruptura entre eles.
\end{abstract}

Termos de indexação: preparo do solo, perfil cultural, unidades morfologicamente homogêneas, recuperação estrutural.

\section{INTRODUCTION}

The great challenge for contemporary society is to find sustainable development models. So far, these models have been based mainly on the economic performance. Of the current economic activities, conservationist tropical livestock farming comes closest to the broad concept of sustainability, due to the maintenance of natural resources, generating wealth and making farming communities economically viable. In balanced biomes with a natural potential for livestock farming, the preservation of natural resources begins with the concern for conservation of the soil and soil structure, due to interactions with other resources such as air and water. Soil structure is the property most affected by the management system.

Intensive soil preparation can lead to a structural modification, predisposing conditions to the formation of compact layers, reduced aggregate stability and proportionally increasing micropores, and promoting soil loss (Souza \& Alves, 2003). As the soil structure is degraded, it becomes less favorable for plant growth and development (Albuquerque et al., 1995). Gaseous exchange, biological activity and the effects of water are directly related to the soil structure, which is possibly the most important factor in soil fertility, since it determines the root-soil interface during plant growth. Adequate rooting of plants is a consequence of soil fertility and structure, and roots are important allies in soil conservation and recovery.
The use of cropping systems that conserve and protect the soil by continuous application of organic residues is fundamental to maintain a good soil structure (Silva et al., 2000). A strategy recommended to mitigate the effects of soil tillage is the use of cover crops or green manure. Calegari (1993) cited green manure as one of the leading sustainable techniques of improving the use of organic matter to benefit the soil. The objective of this technique is to protect the soil surface and improve and conserve the soil physical, chemical and biological properties (Calegari et al., 2008). The use of green manure contributes to diversify the root system and improves the soil structure, promoting soil aeration and water infiltration, resulting in greater root penetration (Bertol et al., 2004). Green manure also increases the soil biological activity, improving the uptake of chemical fertilizers and reducing costs for mineral fertilization (Carvalho et al., 2004).

The legume family has been widely used as green manure due to the capacity to fix $\mathrm{N}_{2}$, the high contents of N-containing organic compounds and the generally fairly deep, well-branched root system that can reach the deeper soil layers (Cardoso et al., 2006; Guimarães et al., 2008). Thus, in the systemic and holistic context of assessing the effects of livestock farming, the diversification of root systems plays a fundamental role.

The use of methods to quantify and qualify the structural soil conditions in the different cropping systems is important for assessing soil quality, 
considered an indicator of sustainability in land management and use systems (Arshad et al., 1996). Tavares Filho et al. (1999) and Neves et al. (2003) demonstrated the need for more detailed information on the soil structure in the field, with the aim of analyzing the effects of different agricultural practices on soil morphology. This concept has been increasingly applied using the so-called Crop Profile, which identifies a set of soil units created by the use of agricultural implements, root behavior and the influence of natural factors (Pereira Neto \& Guimarães, 2005), providing a differentiated view of agronomic problems, particularly in the analysis of effects of agricultural land use (Tavares Filho et al., 1999).

According to Tamia et al. (1999), the different structures of a crop profile are referred to as Homogeneous Morphological Units (HMU), and according to Pereira Neto et al., (2007), they can be quantified using Geographic Information Systems (GIS), i.e., computer systems for analyzing, mapping and quantifying areas of the Earth surface.

Thus, the purpose of this study was to assess and quantify the homogeneous morphological units in soil under conventional tillage with mechanized and animal traction, and to assess the effects of crop succession and intercropping with jack bean (Canavalia ensiformis L.) on the soil structure.

\section{MATERIALS AND METHODS}

The experiment was initiated in the 2003/2004 growing season in five municipalities and six sites of the Southern-Central region of Paraná State - Brazil (Table 1), in family farming areas. The climate was classified as Cfb (subtropical) in the Köppen system, with rainfall throughout the year and a mild summer. The annual average temperature is around $17^{\circ} \mathrm{C}$. The annual rainfall index varies between 1,200 and $1,800 \mathrm{~mm}$. The winter is harsh, generally humid and frosts occur between May and September. The predominant landscape in the region ranges from undulating to mountainous, with elevations ranging from 800 to $1,300 \mathrm{~m}$.

The plots were conventionally tilled with mechanized and animal traction, as used routinely by farmers. The soil was prepared in the winter for green manure and in the summer for maize (Table 1).

The plots were used for two crops (Table 2) and their effects on the soil structure compared. In the summer, maize (Zea mays) and maize intercropped with a legume (jack bean - Canavalia ensiformis) was planted. In the winter, a mixture of green manures was grown, with white lupine (Lupinus albus), cultivated radish (Raphanus sativus), black oat (Avena strigosa), corn spurry (Spergula arvensis), and garden vetch (Vicia sativa).

The soil morphostructure was characterized according to the cultivated soil profile method (Manichon \& Gautronneau, 1996), modified by Tavares Filho et al. (1999).

The profiles were analyzed in April 2006 during the crop cycle, grown as sole maize or maize intercropped with jack bean (sf and cf, respectively). Trenches (length $1.5 \mathrm{~m}$, depth $0.50 \mathrm{~m}$ ) were opened perpendicular to the crop rows in $1,250 \mathrm{~m}^{2}$ plots.

Schematics of the soil profiles delimiting homogeneous morphological units (HMU) on a scale of 1:10 were scanned and imported into ArcView v.8.3, and georeferenced with control points at the four vertices of the profile, graduated in centimeters $(0$ $50 \mathrm{~cm}$ vertically and $0-150$ horizontally), representing HMU areas and an adjustment area (S) with the function of offsetting irregularities of the profile surface.

Three charts were prepared for each profile: the first shows the HMUs of the profile, the second the layers in $10 \mathrm{~cm}$ intervals and a third the profile perimeter only. The last chart was used as a template for trimming the first two to exactly the same size. Next, the HMU chart was intersected with the depth chart, to obtain a fourth chart with the areas of each

Table 1. Description of the areas studied

\begin{tabular}{lll}
\hline Municipality & \multicolumn{1}{c}{ Soil } & \multicolumn{1}{c}{ Management system } \\
\hline Palmeira & $\begin{array}{l}\text { Cambissolo (CB) } \\
\text { (US:Inceptisol) }\end{array}$ & Conventional cropping with plowing and harrowing \\
$\begin{array}{l}\text { Lituruna } \\
\text { (Iratinzinho) } \\
\text { Rio Azul }\end{array}$ & $\begin{array}{l}\text { Cossolo (LT) } \\
\text { (US: Oxisol) }\end{array}$ & Conventional cropping with plowing and harrowing \\
Cruz Machado & $\begin{array}{l}\text { Neossolo (NE) } \\
\text { Argissolo (AR1) }\end{array}$ & Conventional cropping (moldboard plow and disk harrow) using animal traction \\
Bituruna & Contional cropping (plow and disk harrow) using animal traction \\
& $\begin{array}{l}\text { Argissolo (AR2) } \\
\text { (US: Alfisol) }\end{array}$ & Conventional cropping (plow and disk harrow) using animal traction \\
\hline
\end{tabular}


Table 2. Succession systems of the crops evaluated

\begin{tabular}{|c|c|c|c|c|c|c|}
\hline Crop succession & $\begin{array}{c}\text { Winter } \\
03\end{array}$ & $\begin{array}{c}\text { Summer } \\
03 / 04\end{array}$ & $\begin{array}{c}\text { Winter } \\
04\end{array}$ & $\begin{array}{c}\text { Summer } \\
04 / 05\end{array}$ & $\begin{array}{c}\text { Winter } \\
05\end{array}$ & $\begin{array}{c}\text { Summer } \\
05 / 06\end{array}$ \\
\hline $\begin{array}{l}\text { S1: Maize and mixture of green manures } \\
\text { (white lupine, cultivated radish, lopsided oat, } \\
\text { corn spurry and garden vetch) - continuous }\end{array}$ & $\begin{array}{l}\text { Green } \\
\text { Manures }\end{array}$ & Maize & $\begin{array}{l}\text { Green } \\
\text { Manures }\end{array}$ & Maize & $\begin{array}{l}\text { Green } \\
\text { Manures }\end{array}$ & Maize \\
\hline $\begin{array}{l}\text { S2: Maize intercropped with jack bean and a } \\
\text { mixture of green manures (white lupine, cultivated } \\
\text { radish, lopsided oat, corn spurry and garden vetch) } \\
\text { - continuous }\end{array}$ & $\begin{array}{l}\text { Green } \\
\text { Manures }\end{array}$ & $\begin{array}{l}\text { Maize + } \\
\text { Jack Bean }\end{array}$ & $\begin{array}{l}\text { Green } \\
\text { Manures }\end{array}$ & $\begin{array}{l}\text { Maize + } \\
\text { Jack Bean }\end{array}$ & $\begin{array}{l}\text { Green } \\
\text { Manures }\end{array}$ & $\begin{array}{l}\text { Maize + } \\
\text { Jack Bean }\end{array}$ \\
\hline
\end{tabular}

HMU per profile depth. The polygon areas were calculated for each scheme (in $\mathrm{cm}^{2}$ ) as described in Pereira Neto et al. (2007).

According to the method of Fonseca \& Fonseca (2004), the area values of these polygons were processed using two statistical methods: ascending hierarchical classification and principal component analysis (PCA). According to the authors, PCA synthesizes the multidimensional variation of the data, ordering them along the axes of the diagram according to the similarity of the variables considered. Ascending hierarchical classification groups soil profiles that are statistically similar. The results are shown in a dendrogram where the shorter the links, the greater the similarity (Fonseca \& Fonseca, 2004). Both statistical methods produce non-parametric evaluation models of the effects of the various variables analyzed. Ascending hierarchical classification groups the plots according to similarities in terms of occurrence of different structures, whereas PCA is used to analyze which structures found in the profiles can be used to cluster the plots.

\section{RESULTS AND DISCUSSION}

The initial layer of the Cambissolo (Inceptisol) profile maize intercropped with jack bean (CBcf) contained predominantly homogeneous soil, with a continuous, cohesive and low-porosity structure, corresponding to a continuously compact $(\mathrm{C} \Delta)$ structure; then a layer of loose, non-compacted, porous soil, consisting of small clods (pt), corresponding to a Lpt structure; followed by a volume of cracked soil (F), with medium-sized clods ( $\mathrm{mt}$ ) resulting from the mechanized action of agricultural implements, where the cracks favored clod formation, corresponding to a Fmt structure; a second layer, indicating the presence of a compact layer $(\mathrm{C} \Delta)$ resulting from the high intensity of the soil preparation operations involving mechanized traction, and finally a layer unaffected by tillage (NAM) (Figure 1).
However, in the surface layer of the Cambissolo profile sole maize (CBsf) cracked structures prevailed with medium (mt) and large clods (gt), corresponding to the Fmt and Fgt structures, and loose soil with fine earth (Ltf), followed by the $\mathrm{C} \Delta$ structure, the compact layer and finally the NAM structure.

The CBsf profile had the greatest amount of roots in the $0-10 \mathrm{~cm}$ layer, due to the presence of the $\mathrm{C} \Delta$ structure below this depth, forming a barrier to root growth. In the percentage analysis of HMUs, CA accounted for 34 and $30 \%$ of the structures found in the profiles CBcf and CBsf respectively (Figure 2). Despite the maize/jack bean intercropping, there was no effect of the legume on the soil structure, due to the presence of compact layers that prevented the roots from colonizing the soil and beginning the recovery of the soil structure.

The structure of the Latossolo (Oxisol) (LT) profiles with sole maize and maize/jack bean intercropping exhibited a compact layer due to the high intensity of soil preparation. In the LTcf profile, the presence of Ltf, $\mathrm{C} \Delta$ and Fgt $\Delta$ structures were observed along the profile, and even a compact layer at a depth of around $10 \mathrm{~cm}$, caused by the use of heavy machinery. In the surface layer, the LTsf profile exhibited an Ltf structure and a volume of Fmt $\Delta$ soil. This was followed by a Fmt $\Delta \mu$ structure consisting of mediumsized clods with intermediate internal porosity. A C $\Delta$ structure was also observed in this same layer. There was no alteration in the soil structure, with predominance of compact, low porosity units $(\Delta)$, with a predominantly cracked (F) (50\%) structure in both profiles, be it sole maize or maize/jack bean intercropping (Figure 2). When evaluating resistance to maize root penetration in a red clay Oxisol (Latossolo Roxo argiloso), Tavares Filho et al. (2001) found a compact layer caused by the use of heavy machinery between the volumes of loose (L) and continuously compact $(\mathrm{C} \Delta)$ soil, which hampered root penetration. Thus, according to these authors, the structural modifications seem to be more restrictive for the root system development in the conventional system, due to the presence of the $\mathrm{C} \Delta$ structure, which characterizes a very compact soil volume. 

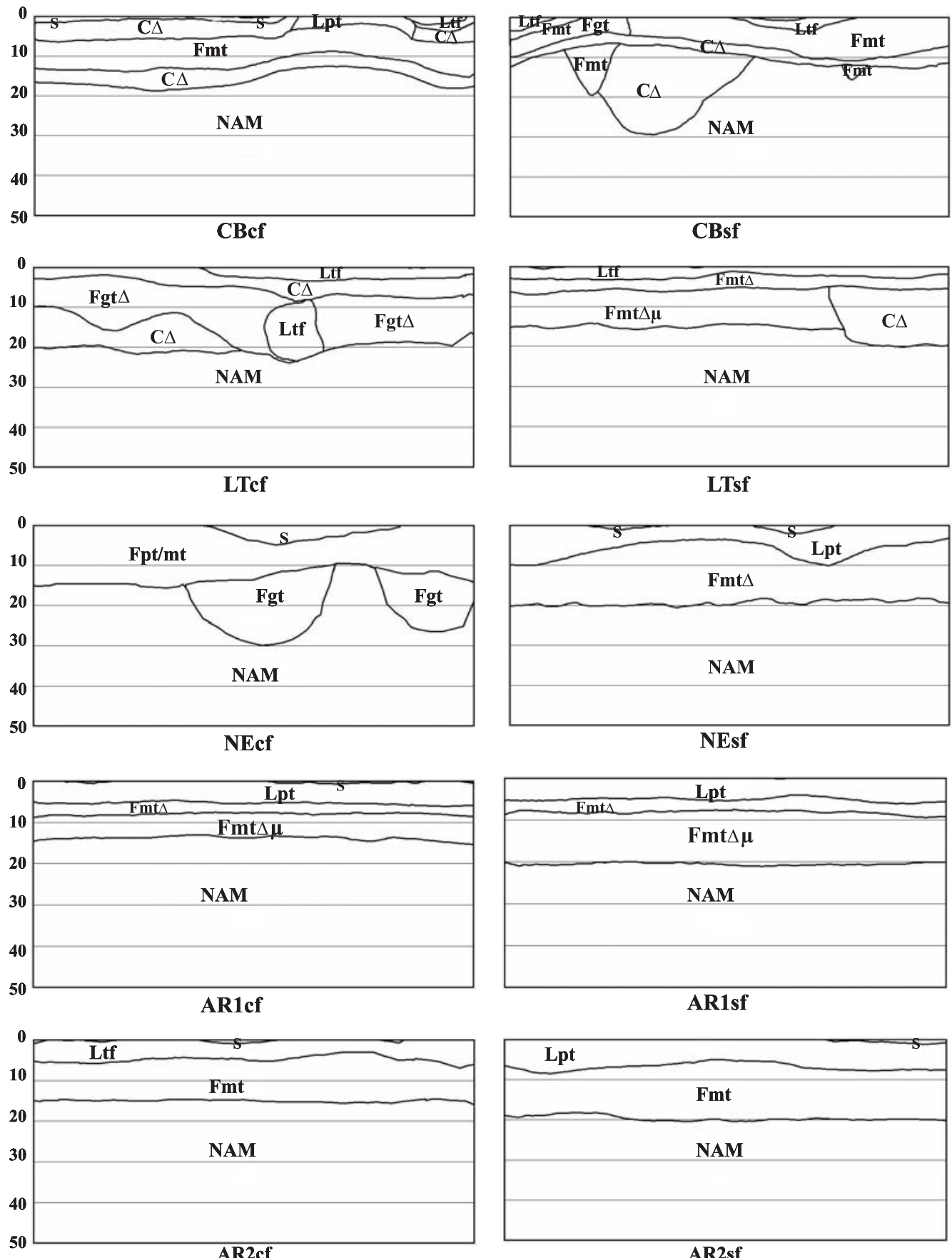

Figure 1. Digitalized crop profiles (profile width: $1.5 \mathrm{~m}$; depth: $0.5 \mathrm{~m} ; \mathrm{S}$ : area adjusted by the software to offset profile surface irregularities; F or C: volume of cracked or continuous soil; $\Delta$ or $\mu$ : compact clods or porous clods; pt, mt, gt: small, medium or large clods; tf: fine earth; L: powdery or loose soil; NAM: soil unaltered by cultivation; Soil: Cambissolo (CB) (Inceptisol), Latossolo (LT) (Oxisol), Neossolo (NE) (Entisol), Argissolo (AR1 and AR2) (Alfisol); cf: maize intercropped with jack bean, sf: sole maize).

The Neossolo (Entisol) profile with maize intercropped with jack bean (NEcf) was generally cracked with small, medium and large clods, corresponding to the Fpt, Fmt and Fgt structures, respectively. The Neossolo profile with sole maize (NEsf) had a surface layer with free, loose soil, consisting of fine earth and small, very porous clods, corresponding to the Lpt structure. This was followed by a cracked structure with medium-sized clods of low porosity, corresponding to the Fmt $\Delta$ structure. We did not observe the presence of the $\mathrm{C} \Delta$ structure in either of the profiles, despite the soil type being vulnerable to compaction. In this area of transition from one soil structure to another the effect of the cover crop is also apparent, due to the higher quantity of cracked structures in the profiles for NEcf and NEsf 


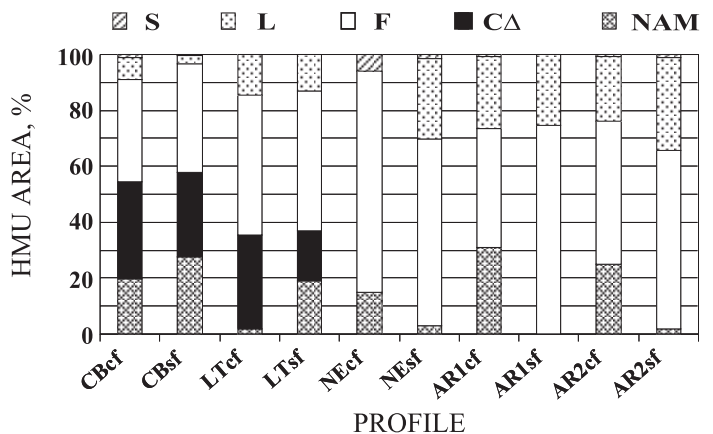

Figure 2. Percentage of homogeneous morphological units (HMUs) in the 0-20 cm layer of the profiles of soil treated with green manure (S: area adjusted by the software to offset profile surface irregularities; L: loose; F: cracked, $\mathrm{C} \Delta$ : continuously compact; NAM: unaffected by cultivation; soil: Cambissolo (CB) (Inceptisol), Latossolo (LT) (Oxisol), Neossolo (NE) (Entisol), Argissolo (AR1 and AR2) (Alfisol); cf: maize intercropped with jack bean, sf: sole maize).

(79 and $66 \%$, respectively) (Figure 2). Roots developed predominantly along the cracks around the clods.

The Argissolo 1(Alfisol) profiles with sole maize (AR1sf) and maize/jack bean intercropping (AR1cf) were similar, with a surface layer with Lpt structure, followed by $\mathrm{Fmt} \Delta / \mathrm{Fmt} \Delta \mu$ structures of low and intermediate porosity, and finally a volume of soil unaffected by human activity (NAM). In the AR1sf profile, the cracked (F) structure was predominant when compared to AR1cf (74 and $43 \%$, respectively) (Figure 2). The recovery response was best in the AR1cf profile and the area of structures affected by human activity was smallest. This effect could be attributed to the cover crop, along with the lower intensity of soil preparation (animal traction). The root system in the profiles with sole maize and maize/ jack bean intercropping was well-developed, with a large amount of roots branching in all directions.

The Argissolo 2 (Alfisol) profiles had an initial layer of free, loose soil, followed by a Fmt structure and finally a NAM structure. There was a predominance of cracked structures for NEcf and NEsf (Figure 2), corresponding to 51 and $63 \%$ respectively. Despite the fact that AR2 contained no profiles with compact structures, the root system growth was poor, which could be explained by a chemical limitation of the soil, one of the factors not analyzed in this study. Therefore, as in the NE and AR 1 profiles, there was a predominance of cracked structures. The $\mathrm{C} \Delta$ structure was not present in areas tilled with animal traction (NE, AR1 and AR2).

The characterization of the various soil profiles in the $0-20 \mathrm{~cm}$ layer directly exposed to climatic agents, cultivation techniques and the vegetation itself showed that the soil was completely transformed in relation to the deeper layer unaffected by anthropogenic factors.
In the areas cultivated with mechanized traction, the presence of compact structures showed that the use of a cover crop was not sufficient to recover the soil structure affected by plowing and harrowing. According to Barreto \& Fernandes (2009), these practices favor the process of organic matter decomposition, reducing the positive effect of the cover crop. It is possible that the short period for which this type of management has been implemented (3 years) and the amount of plant residues left in the soil were not sufficient to alter the soil structure (Minatel et al., 2006). Silva et al. (1999) and Ralisch et al. (2008) verified that the time of application of the practice is directly related to the improvement in the soil physical structure.

Studies have shown that the maintenance and recovery of soil physical properties can be enhanced by cover crops, using plant species with deep and abundant root systems and a high biomass production, which contributes to improve the soil structure. In tropical soils, the inclusion of $\mathrm{N}_{2}$-fixing legumes raises the amount of organic matter in the soil, helping to improve the chemical, physical and biological properties (Franchini et al., 2007; Hungria et al., 2009).

The effects of mechanical tillage of the soil without root enhancement on the physical recovery of the soil are short-lived (Ralisch et al., 2008). Roots are important sources of organic matter for preserving the soil structure, by exudation as well as decomposition (Perfect et al., 1990). Besides, roots that penetrate compact layers and then decompose, leave channels which favor water circulation and gas diffusion within the soil profile (Gonçalves et al., 2006).

It should be borne in mind that crop profiles under field conditions are affected by numerous other variables that can produce a wide range of effects, including the natural soil variability and the variety of conditions under which farming operations are carried out.

The hierarchical classification shown in the dendrogram (Figure 3) divides the soil profiles into two statistically similar groups. The first group contains the profiles AR1sf, AR2sf, NEcf and NEsf, characterized by a higher abundance of L, F with medium clods compact (mt $\Delta$ ) structures resulting from tillage operations that make the soil more vulnerable, mainly due to the predominance of the $\mathrm{L}$ structure in the surface layer. The L, F and mainly NAM structures in the second group, containing the profiles AR1cf and AR2cf (intercropped with jack bean), confirmed the similarity of structures resulting from the use of animal traction, which has a less disturbing effect on the soil. Furthermore, the second group contains similar profiles (with sole maize and maize/ jack bean intercropping), and also the LT profiles, with sole maize and maize/jack bean intercropping. This latter group, with the exception of AR1 and AR2, consists of profiles affected by a more aggressive soil preparation involving the use of mechanized methods. 


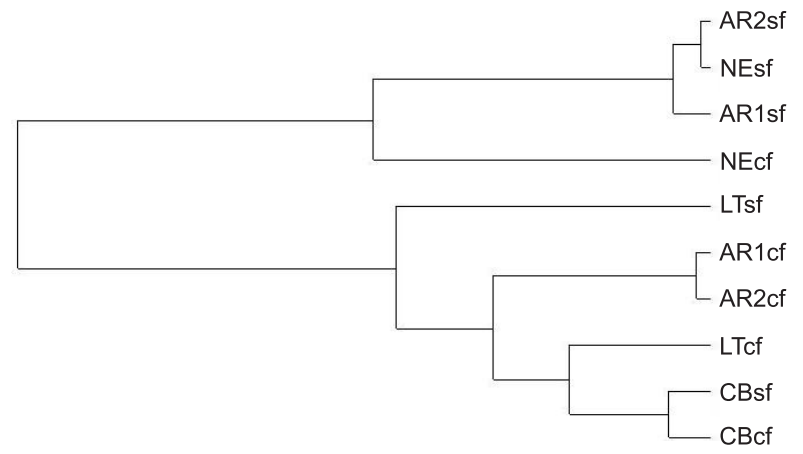

Figure 3. Ascending hierarchical classification of profiles in the 0-20 cm layer. (Soil: Cambissolo (CB) (Inceptisol), Latossolo (LT) (Oxisol), Neossolo (NE) (Entisol), Argissolo (AR1 and AR2) (Alfisol); cf: maize intercropped with jack bean, sf: sole maize).

Using animal traction, these operations are slower, the implements lighter and the structural degradation less marked. The use of jack bean as cover crop recovered structures only in cases of a weaker impact of soil preparation. In contrast, in the plots worked with mechanized traction, the impact of soil preparation on the soil structure resulted in higher resistance to root growth, impeding the regeneration of the physical structure by the cover crop.

In an analysis of profiles under different management systems, Pereira Neto et al. (2007) observed that the dendrogram of the 20-30 cm layer was similar to that of the profile as a whole, showing that this is the boundary between the layers disturbed by the action of farming implements and the unaffected lower layers.

\section{CONCLUSIONS}

1. In areas in which the soil was prepared with mechanized traction, the cover crop had no effect of regenerating the soil structure and low-porous, compact soil units were predomimnant, impeding the root system development.

2. The negative impact of soil preparation with animal traction on the soil structure was lower and resulted in the predominance of cracked structures, which allowed root penetration of the plant species intercropped with maize, contributing to the recovery of the soil structure.

\section{ACKNOWLEDGEMENTS}

The authors wish to thank the farmers, the NGO AS-PTA and the CNPq (Brazilian National Research Council) to support this research.

\section{LITERATURE CITED}

ALBUQUERQUE, J.A.; REINERT, D.J.; FIORIN, J.E.; RUEDELL, J.; PETRERE, C. \& FONTIMELLI, F. Rotação de culturas e sistemas de manejo do solo: Efeito sobre a forma da estrutura do solo ao final de sete anos. R. Bras. Ci. Solo, 19:115-119, 1995.

ARSHAD, M.A.; LOWERY, B. \& GROSSMAN, B. Physical tests for monitoring soil quality. In: DORAN, J.W. \& JONES, A.J., eds. Methods for assessing soil quality. Madison, Soil Science Society of America, 1996. p.123141.

BARRETO, A.C. \& FERNANDES, M.F. Manejo da adubação verde sobre atributos químicos e físicos de um Argissolo Amarelo dos Tabuleiros Costeiros. B. Pesq. Desenvol., 55:1-16, 2009.

BERTOL, L.; ALBUQUERQUE, J.A.; LEITE, D.; AMARAL, A.J. \& ZOLDAN JUNIOR, W.A. Propriedades físicas do solo sob preparo convencional e semeadura direta em rotação e sucessão de culturas, comparadas a do campo nativo. R. Bras. Ci. Solo, 28:155-163, 2004.

CALEGARI, A. Aspectos gerais da adubação verde. In: COSTA, M.B.B., coord. Adubação verde no sul do Brasil. Rio de Janeiro, Pta/Fase, 1993. p.1-55.

CALEGARI, A.; HARGROVE, W.L.; RHEINHEIMER, D.S.; RALISCH, R.; TESSIER, D.; TOURDONNET, S. \& GUIMARÃES, M.F. Impact of long-term no-tillage and cropping system management on soil organic carbon in an Oxisol: A model for sustainability. Agron. J., 100:10131019, 2008.

CARDOSO, E.G.; ZOTARELLI, L.; PICCININ, J.L.; TORRES, E.; SARAIVA, O.F. \& GUIMARÃES, M.F. Sistema radicular da soja em função da compactação do solo no sistema de plantio direto. Pesq. Agropec. Bras., 41:493$501,2006$.

CARVALHO, M.A.C.; ATHAYDE, M.L.F.; SORATTO, R.P.; ALVES, M.C. \& ARF, O. Soja em sucessão a adubos verdes no sistema de plantio direto e convencional em solo de Cerrado. Pesq. Agropec. Bras., 39:1141-1148, 2004.

FONSECA, R.C.B. \& FONSECA, I.C.B. Utilização de métodos estatísticos multivariados na caracterização do mosaico sucessional em floresta semidecídual. R. Árvore, 28:351359,2004

FRANCHINI, J.C.; CRISPINO, C.C.; SOUZA, R.A.; TORRES, E. \& HUNGRIA, M. Microbiological parameters as indicators of soil quality under various tillage and croprotation systems in Southern Brazil. Soil Till. Res., 92:1829, 2007.

GONÇALVES, W.G.; JIMENEZ, R.L.; ARAÚJO FILHO, J.V.; ASSIS, R.L.; SILVA, G.P. \& PIRES, F.R. Sistema radicular de plantas de cobertura sob compactação do solo. Eng. Agríc., 26:67-75, 2006.

GUIMARÃES, M. F.; FONSECA, I.C.B.; BROSSARD, M.; PORTELLA, C.M. R.; BRITO, O.R. \& RITCHIE, J.C. Monitoring changes in the chemical properties of an Oxisol under long-term no-tillage management in subtropical Brazil. Soil Sci., 173:408-416, 2008. 
HUNGRIA, M.; FRANCHINI, J.C.; BRANDÃO-JUNIOR, O.; KASCHUK, G. \& SOUZA, R.A. Soil microbial activity and crop sustainability in a long-term experiment with three soil-tillage and two crop-rotation systems. Appl. Soil Ecol., 42:288-296, 2009.

MANICHON, H. \& GAUTRONNEAU, Y. Guía metódica del perfil cultural. La Paz, IBTA/ORSTOM, 1996. 29p. (Informe, 54)

MINATEL, A.L.G.; ANDRIOLI, I.; CENTURION, J.F. \& NATALE, W. Efeitos da subsolagem e da adubação verde nas propriedades físicas do solo em pomar de citrus. Eng. Agríc., 26:86-95, 2006.

NEVES, C.S.V.J.; FELLER, C.; GUIMARÃES, M.F.; MEDINA, C.C.; TAVARES FILHO, J. \& FORTIER, M. Soil bulk density and porosity of homogeneous morphological units by the Cropping Method in clayey Oxisols in Brazil. Soil Till. Res., 71:109-119, 2003

PERFECT, E.; KAY, B.D.; LOON, W.K.P.; van SHEARD, R.W. \& POJASOK, . Factors influencing soil structural stability within a growing season. Soil Soc. Am. J., 54:173-179, 1990.

PEREIRA NETO, O.C. \& GUIMARÃES, M.F. Método para quantificar pequenas áreas (perfil do solo) utilizando SIG. R. Semina Agr., 26:495-500, 2005.

PEREIRA NETO, O.C.; GUIMARÃES, M.F.; RALISCH, R. \& FONSECA, I.C.B. Análise do tempo de consolidação do sistema de plantio direto. R. Bras. Eng. Agríc. Amb., 11:489-496, 2007.
RALISCH, R.; MIRANDA, T.M.; OKOMURA, R.S.; BARBOSA, G.M.C.; GUIMARÃES, M. F. ; SCOPEL, E. \& BALBINO, L.C. Resistência à penetração de um Latossolo VermelhoAmarelo. R. Bras. Eng. Agric. Amb., 12:381-384, 2008.

SILVA, M.L.N.; CURI, N. \& BLANCANEAUX, P. Sistemas de manejo e qualidade estrutural de Latossolo Roxo. Pesq. Agropec. Bras., 35:2485-2492, 2000.

SILVA, J.A.A.; DONADIO, L.C. \& CARLOS, J.A.D. Adubação verde em citros. B. Citrícola, 9:1-35, 1999.

SOUZA, Z.M. \& ALVES, M.C. Movimento de água e resistência à penetração em um Latossolo Vermelho distrófico de Cerrado, sob diferentes usos e manejos. R. Bras. Eng. Agric. Amb., 7:18-23, 2003.

TAMIA, A.; MOREAU, R.; FORTIER, M. \& YORO, G. Influence du travail du sol sur l'évolution physique d'un sol forestier ferrallitique après défrichement motorisé. Étude Gestion Soils, 6:27-29, 1999.

TAVARES FILHO, J.; RALISCH, R.; GUIMARÃES, M. F.; MEDINA, C.C.; BALBINO, L.C. \& NEVES, C.S.V.J. Método do perfil cultural para avaliação do estado físico de solos em condições tropicais. R. Bras. Ci. Solo, 23:393399,1999

TAVARES FILHO, J.; BARBOSA, G.M.C.; GUIMARÃES, M.F. \& FONSECA, I.C.B. Resistência do solo a penetração e desenvolvimento radicular do milho (Zea mays) sob diferentes sistemas de manejo em Latossolo Roxo. R. Bras. Ci. Solo, 25:725-730, 2001. 